\title{
The Relationships between Indonesian Fourth Graders' Difficulties in Fractions and the Opportunity to Learn Fractions: A Snapshot of TIMSS Results
}

\author{
Ariyadi Wijaya \\ Yogyakarta State University, Indonesia, a.wijaya@uny.ac.id
}

This paper reports an exploration into Indonesian fourth graders' difficulties in fractions and their relation to the opportunity to learn fractions students got at schools. The concept of 'opportunity to learn' is often considered as a framework to investigate possible reasons for students' difficulties. The data for this study was drawn from TIMSS 2015 that comprised test results and teachers' responses to TIMSS Teacher Questionnaire. The test and questionnaire data were analysed by using descriptive statistics. In addition to test and questionnaire, this study also included an analysis of Indonesian textbooks in order to get a broader scope of the opportunity to learn. Qualitative approach was used to analyse the textbooks. The analysis of the TIMSS results shows Indonesian students' low conceptual understanding of fractions. Three possible reasons for students' low conceptual understanding were revealed. First, the content of Indonesian curriculum that gave low emphasis on basic concepts of fractions and introduced operations of fractions too early. Second, the Indonesian mathematics textbooks only presented one definition of fractions, i.e. fractions as parts of wholes. Third, there is a limited use of models or representations of fractions in the classroom practices.

Keywords: curriculum, fourth graders, fractions, opportunity to learn, textbooks, TIMSS

\section{INTRODUCTION}

Trends in International Mathematics and Science Study (TIMSS) is a four year study which is conducted by International Association for the Evaluation of Educational Achievement (IEA). The objective of TIMSS is to measure the achievement of fourth and eighth graders in mathematics and sciences. Since 2015, IEA also conducts TIMSS Numeracy which is intended for low performing countries. TIMSS Numeracy is aimed to assess fundamental mathematical knowledge and procedures that are required for success on TIMSS Mathematics - Fourth Grade (Mullis \& Martin, 2013). In contrast to the Programme for International Student Assessment (PISA) which is claimed to be curriculum free, TIMSS has an attachment to curriculum content. The results of TIMSS

Citation: Wijaya, A. (2017). The Relationships between Indonesian Fourth Graders' Difficulties in Fractions and the Opportunity to Learn Fractions: A Snapshot of TIMSS Results. International Journal of Instruction, 10(4), 221-236. https://doi.org/10.12973/iji.2017.10413a 
serve as crucial information for the participating countries to develop strategies and attempts to improve the quality of mathematics and science learning.

In order to measure students' mathematics performance, TIMSS uses mathematics tasks that comprise two domains, i.e. content domain and cognitive domain (Mullis \& Martin, 2013). Content domain refers to the mathematics contents or topics which are assessed. In TIMSS Mathematics - Fourth Grade there are three domains of content, i.e. numbers, geometric shapes and measures, and data display. In addition to the content domains, students also have to cope with cognitive domains that measure the level of students' cognitive skills, which include knowing, applying, and reasoning. The domain knowing measures factual, conceptual, and procedural knowledge of students. The domain applying measures students' ability to apply their conceptual understanding in various problem situations. The third domain, reasoning, focuses on non-routine problems with complex contexts that require multiple steps.

In 2015 Indonesia, for the first time, participated in TIMSS for the fourth grade. The average score of Indonesian fourth graders in TIMSS 2015 was 397, which was far below the TIMSS scale centerpoint of 500. Only five countries had lower performance than Indonesia, i.e. Jordan (388), Saudi Arabia (383), Morocco (377), South Africa (376), and Kuwait (353). A surprising result was found when zooming in the TIMSS results on students' responses to tasks which addressed the topic of fractions. On average only $24.45 \%$ of Indonesian students could correctly answer tasks about fractions. This percentage was below the average percentage of other countries which had lower TIMSS scores, i.e. Saudi Arabia (29.42\%) and Kuwait (25.18\%). A similar result was found for TIMSS Numeracy in which the average percentage of correct answers of Indonesian students $(42.67 \%)$ was also lower than that of students from lower performing countries; i.e. Jordanian (46.76\%) and South African (48.72\%).

A concept of 'opportunity to learn' is often considered as a crucial concept to investigate possible reasons for students' low performance (Brewer \& Stasz, 1996; Hiebert \& Grouws, 2007). Opportunity to learn covers the content of curriculum, instructional strategies, and also instructional resources such as textbooks. In the First International Mathematics Studies (FIMS), opportunity to learn was measured by examining the content of curriculum through a teacher questionnaire aiming to reveal mathematics topics that had been learned by students before the period of test (Husén, 1967). In an addition to the content of curriculum, content of textbooks is also considered as a measure of opportunity to learn because it is an important factor that might influence students' achievement. Several studies revealed a relation between students' performance and the content of textbooks they read (see: Tornroos, 2005; Wijaya et al., 2015; Xin, 2007). Considering the advantages of the concept opportunity to learn, this study was aimed to explore possible explanations for students' difficulties by using this concept as the main reference. 


\section{THEORETICAL REVIEW}

\section{Fractions: Concept and Students' Difficulties}

Before 1970s the concept of fractions was mainly considered from the perspective of part-whole relationship. This concept refers to a quantity that is divided into equal parts in which a fraction is a comparison between the number of selected equal parts to the total number of parts. A fraction as a part of whole does not only refer to the partition of a single continuous object, but could also refer to the partition of a set of discrete objects (Lamon, 1999). In 1970s, Kieren (1976) proposed that the concept of fractions as part-whole comprised four sub-constructs, i.e. ratio, operator, quotient, and measure. The 'ratio' sub-construct expresses the notion of a comparison between two quantities (Carraher, 1996). The 'operator' sub-contract refers to the application of a function to a number, an object, or a set (Behr, Harel, Post, \& Lesh, 1993). The 'quotient' subconstruct considers a fraction as the result of a division (Charalambous \& Pitta-Pantazi, 2007). The 'measure' sub-construct refers to the position of a fraction on a number line (Charalambous \& Pitta-Pantazi, 2007). Unlike Kieren who considered part-whole relationship has a higher level than the four sub-constructs of fractions, Behr, Lesh, Post, and Silver (1983) recommended the part-whole relationship as a distinct subconstruct of fractions. Among the aforementioned sub-constructs of fractions, TIMSS Fourth Grade only focuses on the part-whole sub-construct and the measure subconstruct (Mullis \& Martin, 2013). The part-whole sub-construct comprises parts of wholes and parts of a set. In an addition to the basic concept of fraction, Behr and his colleagues distinguished the operations of fractions into equivalence, addition, and multiplication. Regarding the operations of fractions, TIMSS includes equivalence, order of fractions, addition, and subtraction.

Studies on the teaching and learning of fractions revealed that many students have difficulties with fractions. According to Ni and Zhou (2005), most of students' errors and misconceptions are due to a so called 'whole number bias' in which students' prior knowledge of numbers do no longer hold for fractions. The multiple meanings of fractions also lead to students' difficulties. With this respect, several studies (e.g. Charalambous \& Pitta-Pantazi, 2007) revealed that students mostly succeed in tasks related to the part-whole sub-construct, but experience difficulties in solving tasks related to the measure sub-construct. The notation of fractions also contributes to students' difficulties with fractions ((Van de Walle et al., 2013). With respect to the operations of fractions, students do equally well in addition, subtraction, multiplication, and division when the tasks are presented as computations. However, when the tasks are given in the form of word problems addition is the easiest and multiplication is the most difficult (Aksu, 1997).

\section{Opportunity to Learn: Curriculum, Teachers' Teaching Practices, and Textbooks}

Interest in the concept of opportunity to learn is increasing because studies on this concept provide policymakers with information on the implementation of their policies, and at school level such studies provide information about the strengths and weaknesses of school practice and the appropriateness of the used materials or resources. In FIMSS, 
opportunity to learn is defined as whether students have had the opportunity to learn the particular topics that were tested (Husén, 1967). Another perspective of opportunity to learn was coined by Carroll (1963) more than five decades ago when she concerned sufficient time for students to learn. In international comparative studies opportunity to learn is considered to find an explanation for the differences between students' performance across countries with different educational systems (see Husén, 1967; Schmidt et al., 1997; Valverde et al., 2002).

A broader scope of opportunity to learn was proposed by Brewer and Stacz (1996) who distinguish three overlapping dimensions to measure opportunity to learn. The first dimension is the curriculum content which focuses on whether students have been taught the topics that are required to attain particular standards. The second dimension is instructional strategies that assesses the learning strategies or approaches that are used by teachers. The third dimension is instructional resources that concern the quality of learning resources including textbooks.

\section{METHOD}

The present study was driven by a sequential explanatory research design. This research design was selected because the present study was aimed to investigate students' difficulties in solving TIMSS items and then explore possible explanation for these difficulties. According to Creswell et al. (2003), a sequential explanatory design is started from quantitative study and followed by qualitative study to explain the findings of the quantitative results. However, this study modified the steps of this sequential explanatory design by adding another quantitative study after the first quantitative study (see Figure 1). QUAN 1 was investigating students' difficulties, whereas QUAN 2 was examining the survey result which was aimed to find an explanation for QUAN 1. QUAL 1 was a study on a textbook which was aimed to explain QUAN 1 and also to confirm QUAN 2. Lastly, QUAL 2 was interviewing teachers to find an explanation for QUAN 1.

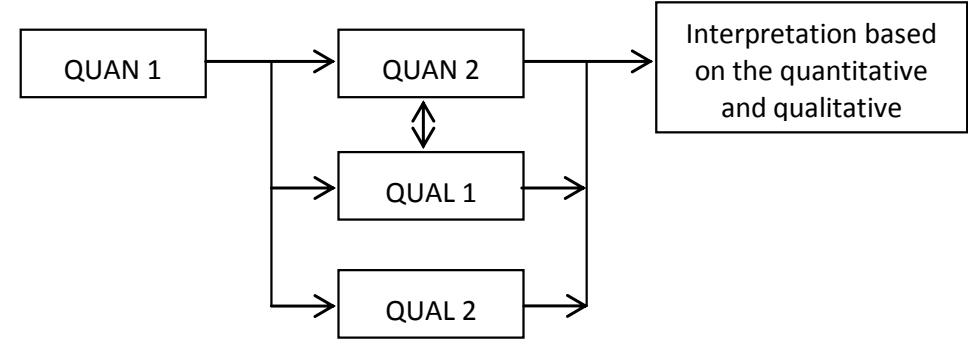

Figure 1

The steps of the modified sequential explanatory design

\section{Data Collection}

The present study used secondary data that was drawn from the database of TIMSS 2015; therefore no instrument was directly used to collect the data. The TIMSS data which was used in this study consisted of test results and teachers' responses to Teacher 
Questionnaire. Test data was used to investigate students' performance in fractions, whereas the questionnaire data was aimed to explore the scope of fractions in the curriculum. The test results were restricted only to students' responses to 13 items addressing fractions in TIMSS Mathematics - Fourth Grade and 8 items about fractions in TIMSS Numeracy. With regard to the questionnaire data, the present study only focused on two items asking about the topic of fractions in the curriculum; i.e. " ... when the students in this class have been taught ... the concepts of fractions (fractions as parts of a whole or of a collection, or as a location on a number line)" and "... when the students in this class have been taught adding and subtracting with fractions, comparing and ordering fractions." Teachers were asked to choose: (a) 'mostly taught before this year' if the topics were in the curriculum before fourth grade; (b) 'mostly taught this year' if the topics were taught half this year but not yet completed; and (c) 'not yet taught or just introduced' if the topics are not in the curriculum.

In addition to TIMSS 2015 data, the present study also included textbooks in order to investigate the opportunity to learn fractions provided by Indonesian textbooks. Indonesian curriculum mandated the use of thematic approach for elementary school and, consequently, textbook were written in accordance with the themes, i.e. eight themes for grade 1 to grade 3 and nine themes for grade 4 to grade 6 . For the purpose of the present study, only the textbooks for grade three which were analyzed because it was one grade below TIMSS' targeted grade. Moreover, these textbooks were restricted only to two textbooks that included textbook theme 2 (Buku Tematik Terpadu - Tema 2: Perkembangan Teknologi) and textbook theme 5 (Buku Tematik Terpadu - Tema 5: Mengenal Olah Raga dan Permainan Tradisional) because only in these themes the textbooks contained fractions. The two textbooks were electronic textbooks which were published by the Indonesian Ministry of Education and Culture in 2015. The last data included in the present study was teachers' opinion that was obtained from interviewing elementary school teachers. Five elementary school teachers (T1 - T5) were interviewed after teaching fractions. The teachers were asked about their regular approach in teaching fractions.

\section{Participants}

With regard to the test and questionnaire data, the TIMSS database did not provide information about the number of the participants. Therefore, among the four studies mentioned in Figure 3, only the QUAL 2 study which directly involved participants. Participants of the QUAL 2 study were five elementary school teachers (2 males and 3 females) which were randomly selected.

\section{Data Analysis}

Quantitative analysis, in particular descriptive statistics, was used to analyze the test results and teachers' responses to the questionnaire. A simple correlation between the test results and teachers' responses was explored by a means of scatter plot. With regard to the textbooks, this data was analyzed qualitatively by following Charalambous et al.'s (2010) 'vertical analysis', i.e. analyzing textbooks by focusing on the characteristics of their content which in the present study was limited to the way fractions were presented 
in the textbooks. Lastly, qualitative analysis was also used to analyze the interview data for which teachers' responses were analyzed and described descriptively.

\section{FINDINGS}

\section{Indonesian Fourth Graders' Performance in Fractions}

The analysis of students' responses to TIMSS test items about fractions showed that Indonesian students underperformed students from Jordan, Saudi Arabia, South Africa, and Kuwait (see Table 1). Focusing on the percentage of correct answer for every test item about fractions, Indonesian students' performance for some items was obviously lower than the performance of students from other countries (see Figure 2). For example, test item M07_04 which was about fractions as parts of a set. Only 6.8\% Indonesian fourth graders could answer the item correctly, which was far below the percentage of correct answer of students from Saudi Arabia (53.3\%), Kuwait (43.7\%), and international average (55.3\%). In addition to fractions as parts of a set, word problems were also difficult for Indonesian students. It can be seen from the low percentage of correct answer of Indonesian students for tasks in the form of word problems such as M13_04A and M13_04B. Unsatisfactory results were also found in TIMSS Numeracy which was actually easier than TIMSS Mathematics - Fourth Grade (see Figure 3).

Table 1

The results of the low performing countries in TIMSS Mathematics Fourth Grade and TIMSS Numeracy 2015

\begin{tabular}{lcc}
\hline \multicolumn{2}{c}{ TIMSS Mathematics - Fourth Grade } \\
\hline Country & $\begin{array}{c}\text { TIMSS } \\
\text { Score }\end{array}$ & $\begin{array}{c}\text { Correct } \\
\text { answer }\end{array}$ \\
\hline International & 500 & $46.98 \%$ \\
\hline Indonesia & 397 & $24.45 \%$ \\
\hline Saudi Arabia & 383 & $29.42 \%$ \\
\hline Kuwait & 353 & $25.18 \%$ \\
\hline
\end{tabular}

\begin{tabular}{lcc}
\hline \multicolumn{3}{c}{ TIMSS Numeracy } \\
\hline Country & $\begin{array}{c}\text { TIMSS } \\
\text { Score }\end{array}$ & $\begin{array}{l}\text { Correct } \\
\text { answer }\end{array}$ \\
\hline International & 500 & $47.33 \%$ \\
\hline Indonesia & 397 & $42.67 \%$ \\
\hline Jordan & 388 & $46.76 \%$ \\
\hline South Africa & 376 & $48.72 \%$ \\
\hline
\end{tabular}

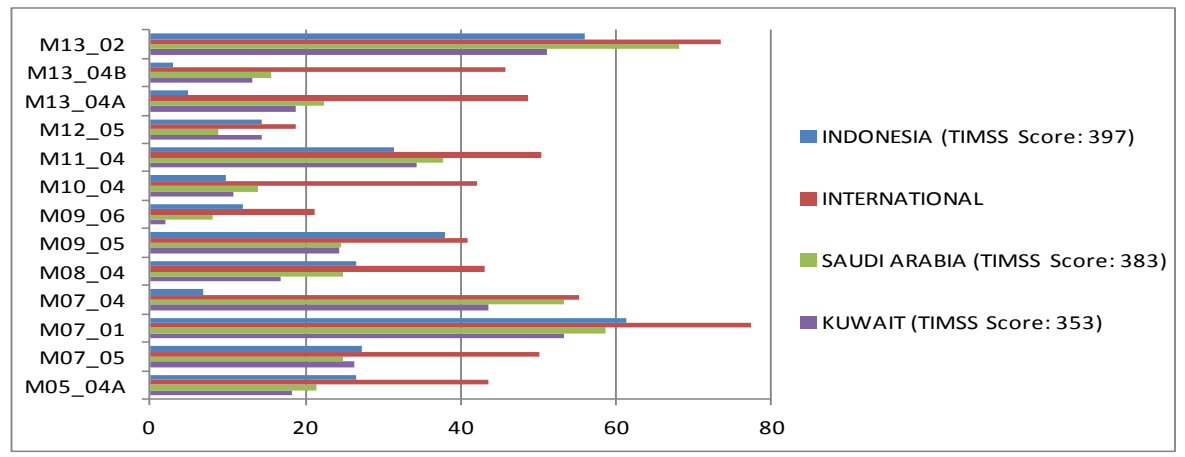

Figure 2

Percentage of Correct Answer for Items about Fractions in TIMSS 2015 


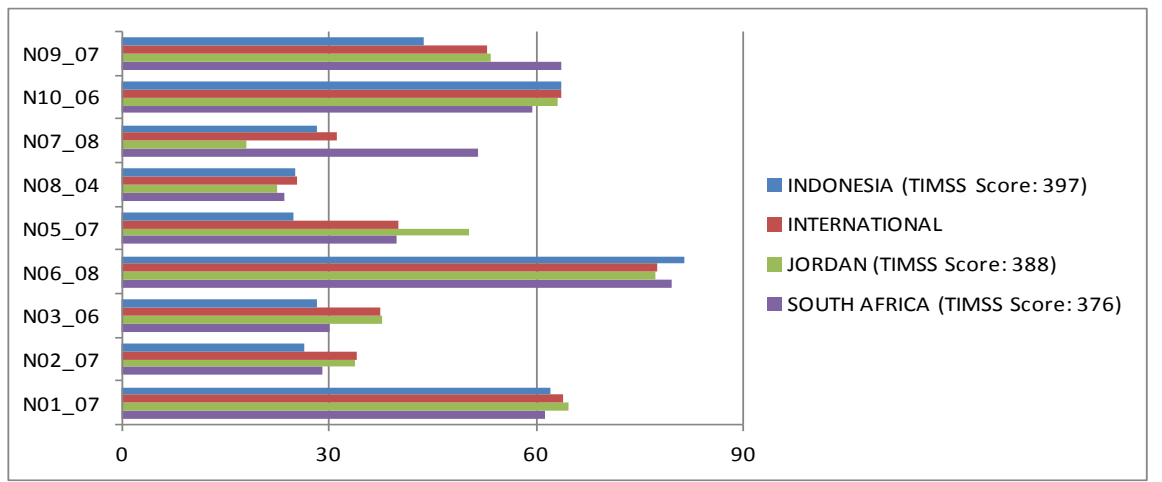

Figure 3

Percentage of Correct Answer for Items about Fractions in TIMSS Numeracy

Of the 13 test items in TIMSS 2015, eight items addressed basic concepts of fractions and five items were about operations of fractions. The results of analysis revealed that the percentage of correct answer of Indonesian students for both areas were equally low. A different case was found in Saudi Arabia, Kuwait, and international average in which the percentage of correct answer for items about basic concepts of fractions was remarkably higher than the answer for items about operations of fractions. Such pattern was also found in three out of five top performing countries (see Figure 4). The pattern with regard to the difference between basic concepts and fractions found in Singapore and Hongkong was relatively similar to Indonesia in which students performance in both areas of fractions were relatively equal. However, students from Singapore and Hongkong already had a great performance in basic concepts of fractions. This result indicates Indonesian fourth graders' low understanding of the basic concepts of fractions. [Note: only three low performing countries were included in the comparison because South Africa, Morocco, and Jordan only participated in TIMSS Numeracy].

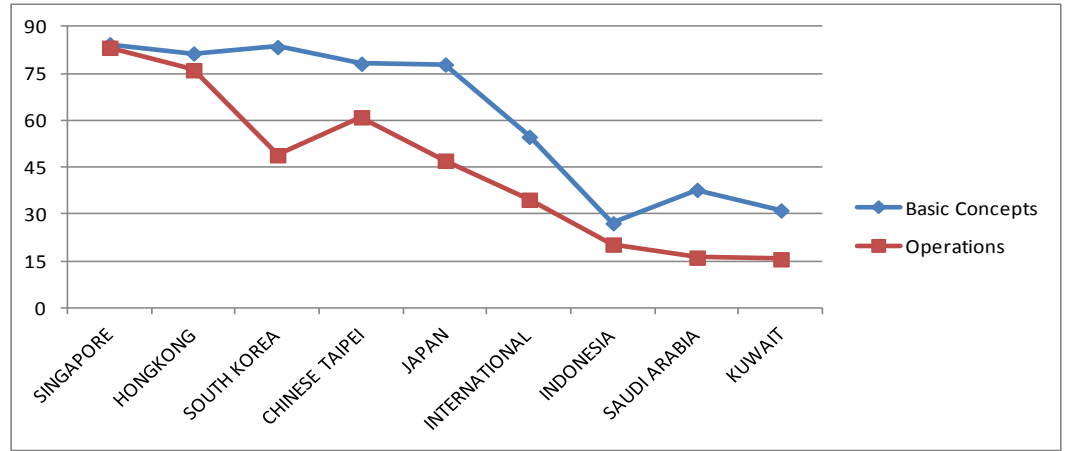

Figure 4

Comparison between students' performance in basic concepts and in operations of fractions 


\section{Opportunity to Learn Fractions Offered by Indonesian Curriculum}

To find possible explanation for the low performance of Indonesian students in fractions, the present study investigated the opportunity to learn fractions offered by the content of Indonesian curriculum. The curriculum content was explored from the perspective of teachers' responses to two items of the Teacher Questionnaire, i.e. when the students have been taught the concepts of fractions and when the students have been taught the operations of fractions. Teachers' responses to these two items reveal that both basic concepts and operations of fractions have been taught since in the third grade in almost all participating countries. The proportion of basic concepts of fractions and operations of fractions taught in third grade varied among TIMSS participating countries. The international average shows that $72 \%$ of topic of fractions taught in third grade was about basic concept of fractions and the remaining $28 \%$ was about operations of fractions. The present study explored the relation between the proportions of these two areas of fractions taught in third grade with fourth graders' performance in fractions in the majority of TIMSS participating countries (Figure 5). The vertical axis on Figure 5 represents students' performance in fractions as measured by the percentage of correct answers, whereas the horizontal axis represents the difference between proportions of basic concepts and operations of fractions (i.e. difference $=$ proportion of basic concepts - proportion of operation). Higher value on the horizontal axis means greater emphasis on the basic concepts of fractions. The trendline on Figure 5 indicates that students from countries which give more emphasis on basic concepts tend to have higher performance in fractions than the students from countries with less emphasis on basic concepts.

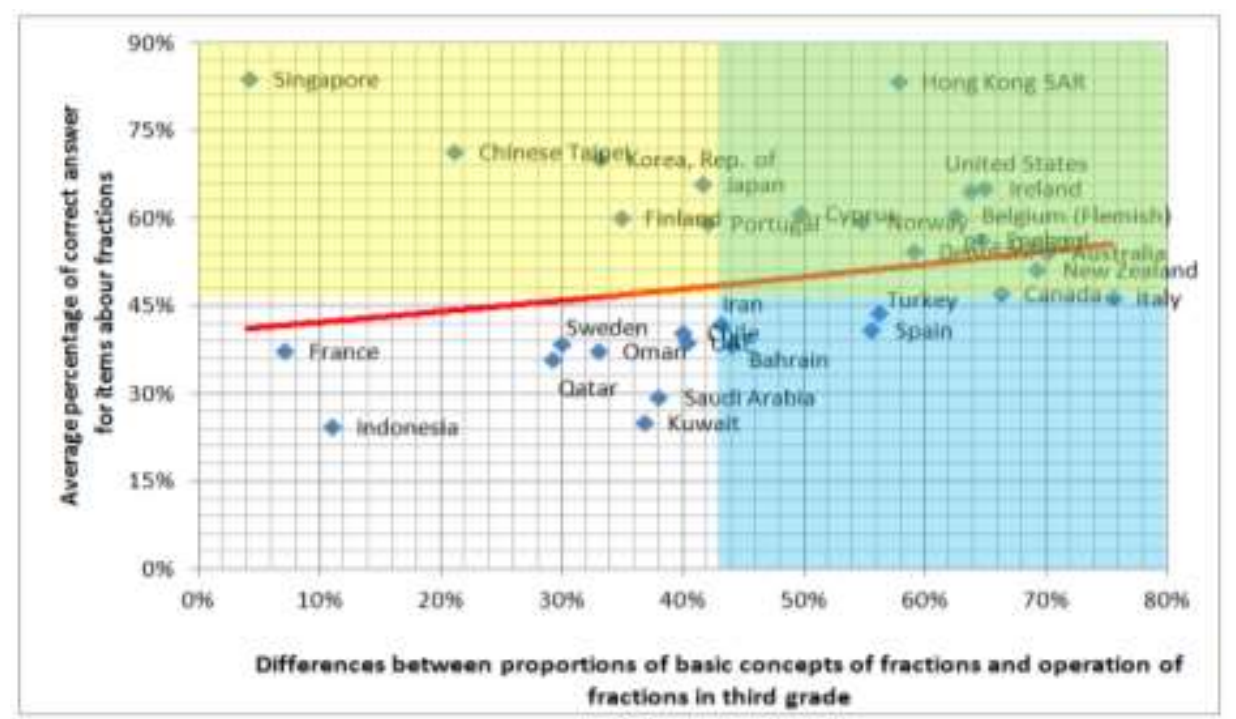

Figure 5

Relation between students' performance in fractions and the emphasis of areas of fractions taught in third grade 
Considering the gap between students' performance in basic concepts and in operations of fractions as reported earlier on Figure 4, the analysis was narrowed down from general performance in fractions to specific performance in each of the two areas of fractions. Due to the workload, this analysis only included the data of five top performing countries and three low performing countries. South Africa, Morocco, and Jordan were excluded from the analysis because they only participated in TIMSS Numeracy which did not include tasks addressing operations of fractions. A Pearson product-moment correlation coefficient was computed to investigate the relationship between the curriculum emphasis and students' performance. The curriculum emphasis was measured by the difference between the proportion of basic concepts and the proportion of operations of fractions. The students' performance was the score for basic concepts subtracted by the score for operations. A positive correlation between the two variables was not found, $\mathrm{r}=.353, \mathrm{n}=9, \mathrm{p}=.351$. Nevertheless, the scatterplot as shown in Figure 6 indicates a tendency that students from countries which in the third grade give more emphasis on basic concepts had a larger difference between their performance in basic concepts and operations of fractions.

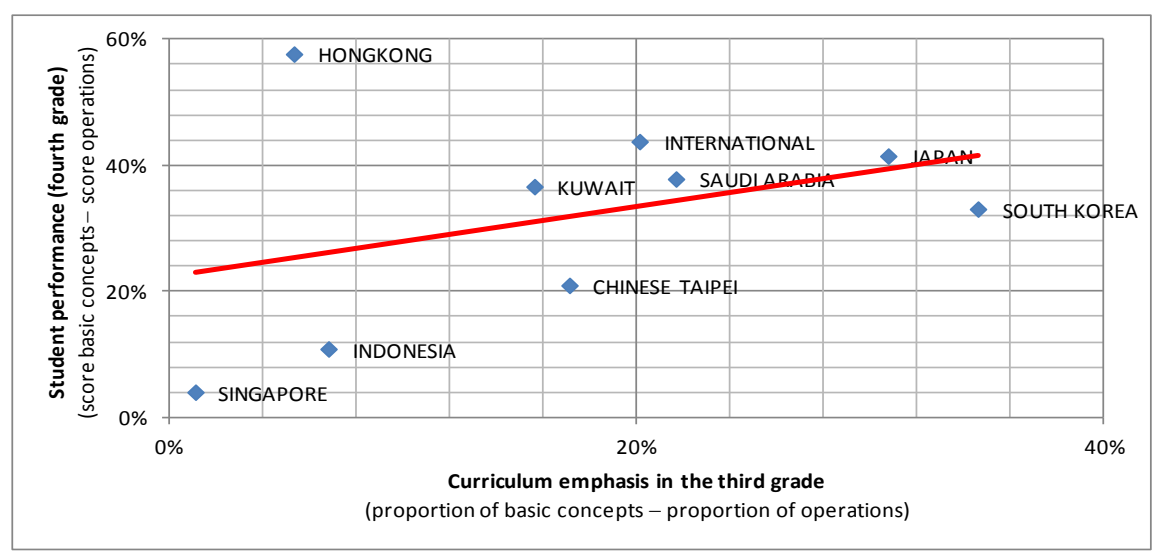

Figure 6

Relation between students' performance and the content of fractions in third grade: A comparison between Indonesia and benchmarking countries

\section{Opportunity to Learn Fractions Offered in Indonesian Textbooks}

To get a broader portrait of possible reasons for Indonesian fourth graders' poor results in fractions, the present study also investigated the opportunity to learn offered in Indonesian textbooks. The textbook analysis focused on the approach that was used to introduce and to deliver the concept of fractions including the basic concepts and operations. With regard to the basic concepts of fractions, the Indonesian textbooks only provided one definition of fractions, i.e. fractions as parts of wholes. None of the textbooks represented fractions as parts of a collection or as a position on the number line. Table 2 shows an example of how Indonesian textbook introduced the concept of fractions for which daily life context was used. 
In the exercise sections Indonesian textbooks also only included fractions as parts of wholes which were represented by shaded area (Figure 7; note: the tasks were translated into English for the purpose of this article). Students were asked to mention the fractions which were represented by given shaded figures. Students were also asked to shade figures to represent given fractions. This restriction might contribute to the low performance of Indonesian students when dealing with fractions as parts of sets (see item M07_04 on Figure 2). In an addition to the restriction of the definition of fractions, with respect to fractions as parts of wholes Indonesian textbooks did not offer enough opportunity for students to do fair sharing by themselves. The textbooks provided a whole unit that was already divided into several equal parts and only asked students to shade the parts that represented a certain fraction (see also Figure 7). Limited opportunity to do fair sharing might lead students to focus only on the number of shaded parts and ignore that all parts must be equal. At the end, it might contribute to students' difficulties in dealing tasks that require students to make the partitions by themselves.

Table 2

An introduction to fractions in Indonesian textbook

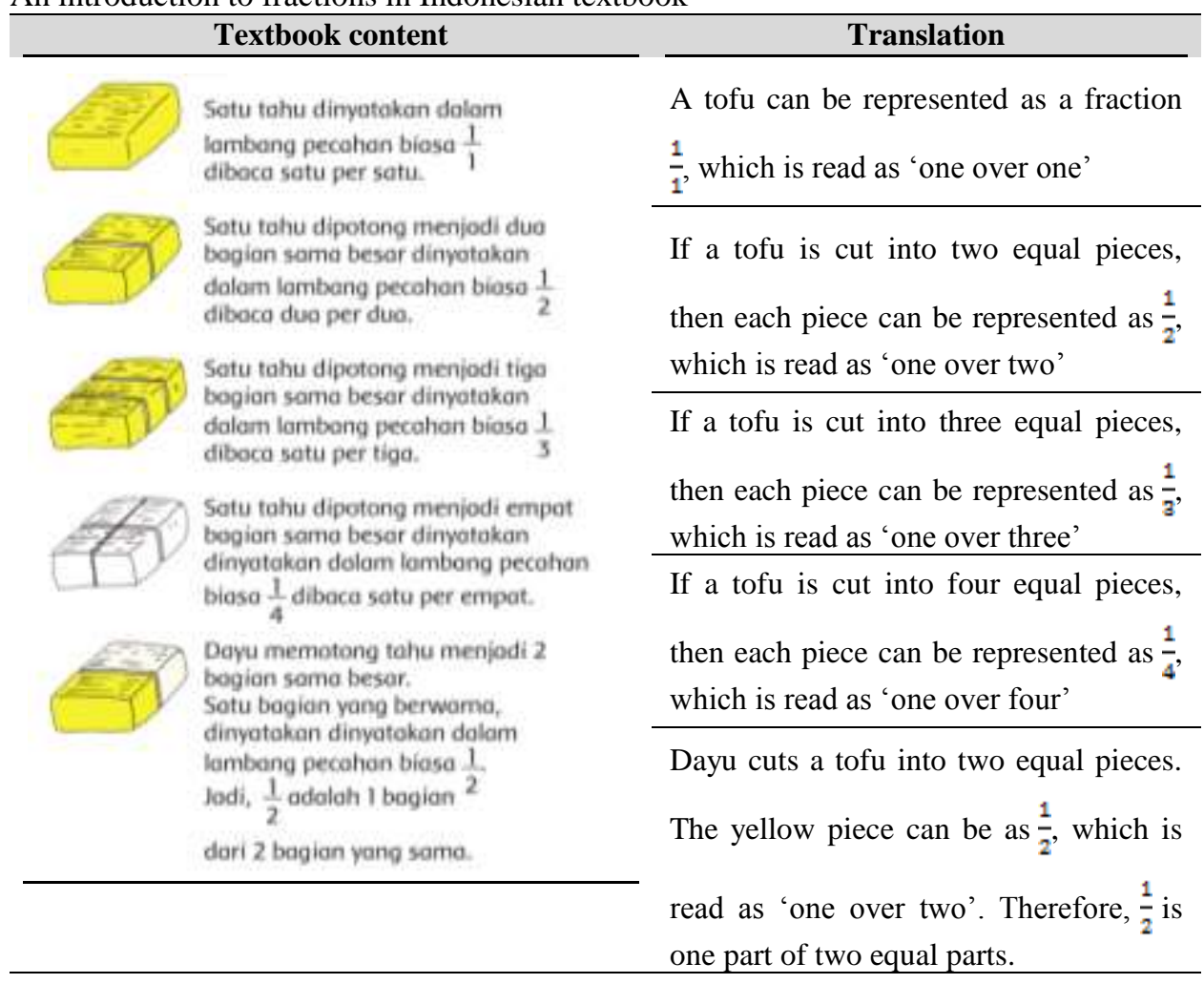




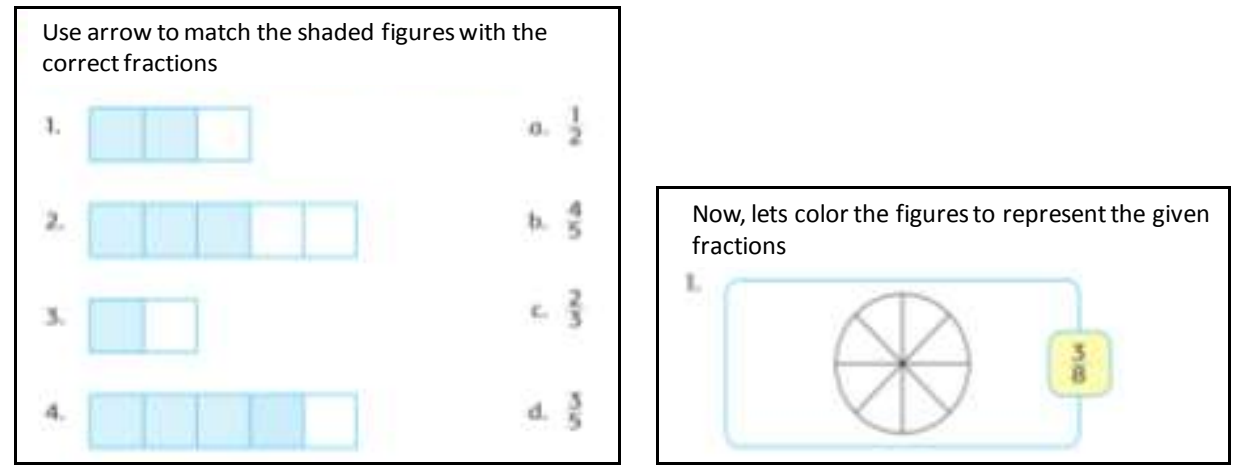

Figure 7

Examples of tasks in an Indonesian textbook

Opportunity to Learn Fractions Offered in Teachers' Teaching Practices

The last dimension of opportunity to learn which was investigated in the present study was teachers' teaching practices. Four elementary teachers were asked about how they usually taught fractions. The teachers reported that they taught fractions by following the textbooks they used (see the comment of $\mathrm{T} 1$ below). The teachers never improvised their practices or added additional content or exercises which were not included in the textbooks. In line with the content of the textbook, the teacher also confirmed that they mostly taught fractions as parts of wholes. With respect to the instructional strategies, the teachers reported that they heavily used expository method and barely used models of fractions and manipulative (see the comment of T2). When discussing manipulative for teaching fractions, T3 thought that the function of manipulative was not to build the idea of fractions, but mainly to visualize fractions or operations of fractions after students grab the mathematical ideas.

\section{T1: "I always follow what is mentioned in the textbooks." \\ T2: "I never used manipulative to model or represent fractions."}

\section{CONCLUSION}

An analysis of the results of TIMSS Mathematics - Fourth Grade and TIMSS Numeracy reveals Indonesian fourth graders' low understanding of basic concept of fractions. With respect to students' difficulties, the findings of this study confirm other studies (e.g. Charalambous \& Pitta-Pantazi, 2007) that the part-whole sub-construct was the easiest concept of fractions for students. In line with Aksu (1997), the present study also reveals an indication that fractions presented as word problems are more difficult for students than fractions as mere computations.

In order to investigate possible factors that might influence students' performance in fractions, by referring to Brewer and Stacz (1996) this study explores the opportunity to learn fractions from three aspects: curriculum, textbooks, and teachers' teaching practices. The selection of these aspects is also in line with the levels of curriculum which are considered in TIMSS: intended curriculum, potentially implemented curriculum (i.e. textbooks), and implemented curriculum (i.e. teaching practices) 
(Schmidt et al., 1997). With respect to the Indonesian curriculum content, the result of the TIMSS teacher survey reveals that in the third grade the teaching of fractions in Indonesia gives low emphasis on the basic concepts of fractions and introduces operations of fractions quite early. Such practice might contribute to Indonesian fourth graders' low performance in dealing with the basic concepts of fractions. This conjecture is in agreement with other researchers that a limited conceptual knowledge of fractions will lead to an instrumental understanding of fractions (Aksu, 1997) and rote learning of fractions (van de Walle et al., 2013). Indonesian fourth graders' low performance in fraction might also be influenced by the way fractions are presented in textbooks. This claim is supported by the finding that Indonesian textbooks only provide one definition of fractions - i.e. fractions as parts of wholes - whereas TIMSS uses three definitions of fractions. The restriction of the definition of fractions in Indonesian textbooks might make students struggle with fractions as parts of a set and fractions as location on number line. This argument is in agreement with the study of Charalambous and Pitta-Pantazi (2007) that students do not have difficulty with fractions as parts of a whole because it is the most frequently appeared sub-construct of fractions in students' mathematics textbooks and, on the contrary, the other sub-constructs of fractions are not emphasized as much as the part-whole. Our last concern regarding possible reasons for students' difficulties with fractions is teachers' teaching practices. With regard to teachers' teaching practices, the teachers rely heavily on the textbooks and rarely use models or manipulative to teach fractions. Such teaching practice limits the opportunity for students to learn fractions because, according to van de Walle et al. (2013) appropriate representations or models could broaden and deepen students' understanding of fractions.

Based on the results of the present study there are important recommendations to consider regarding the teaching and learning of fractions. First, in early grades it is important to give more attention to the basic concepts of fractions because they serve as fundamental basis for students to learn fractions. As recommended by Aksu (1997), "[s]tudents must understand the meanings of fractions before performing operations with them (p. 375)." Similarly, van de Walle et al. (2013) suggest an emphasis on the meaning of fractions rather than on rote procedures for working with fractions. The second recommendation concerns a need to give students opportunity to learn and experience all definitions of fractions. With this respect, Charalambous and PittaPantazi (2007) indicate the importance of a balance in emphasis on the five subconstructs of fractions during classroom instruction. The third recommendation, teachers should use various models, contexts, and also manipulative in the teaching of fractions. This recommendation is in agreement with other studies (e.g. Cramer \& Henry, 2002; Siebert \& Gaskin, 2006) that the effective use of models or manipulative is important to learn fractions.

Although the present study has obtained its objectives, its design is not without flaws. A number of limitations need to be considered regarding the results and the recommendations of the present study. The first limitation is that the students, the textbooks, and the interviewed teachers are not within the same cohort. The analyzed textbooks are published by government and are recommended as the main source in the 
classrooms. However, there is no guarantee that these textbooks were used by the fourth graders who participated in TIMSS study. Similarly, the interviewed teachers might not come from the same schools as the students who participated in TIMSS. Furthermore, the limited number of the interviewed teachers might not reveal the general teaching practices. The second limitation concerns the aspects of opportunity to learn in which the present study only included curriculum, textbooks, and teaching practices. In fact, there are other factors that might contribute to students' difficulties with fractions. For example, as reported by Kele and Sharma (2014) that students' beliefs and attitudes can impact on students' mathematics performance. Classroom characteristics and parental attitudes are also important factors that need to be considered with respect students' mathematics learning (see e.g. Kiwanuka et al., 2017).

\section{ACKNOWLEDGMENT}

I would like to thank the Center for Educational Assessment, the Indonesian Ministry of Education and Culture for allowing me to access Indonesia's data in TIMSS 2015. A shorter version of this paper has been presented at the International Conference on Research, Implementation, and Education of Mathematics and Sciences (ICRIEMS) 2017 in Yogyakarta State University, Indonesia.

\section{REFERENCES}

Aksu, M. (1997). Student performance in dealing with fractions. The Journal of Educational Research, 90(6), 375-380.

Behr, M., Lesh, R., Post, T., \& Silver, E. (1983). Rational number concepts. In R. Lesh \& M. Landau (Ed), Acquisition of Mathematics Concepts and Processes (pp. 91-125). New York: Academic Press.

Behr, M. J., Harel, G., Post, T., \& Lesh, R. (1993). Rational numbers: Toward a semantic analysis-emphasis on the operator construct. In T.P. Carpenter, E. Fennema, \& T.A. Romberg (Ed), Rational Numbers: An Integration of Research (pp. 13-47). New Jersey: Lawrence Erlbaum Associates.

Brewer, D. J., \& Stacz, C. (1996). Enhancing opportunity to learn measures in NCES data. Santa Monica, CA: RAND.

Carraher, D. W. (1996), Learning about fractions. In L.P. Steffe, P. Nesher, P. Cobb, G.A. Goldin and B. Greer (Ed), Theories of Mathematical Learning (pp. 241-266). New Jersey: Lawrence Erlbaum Associates.

Carroll, J. (1963). A model of school learning. Teachers College Record, 64, 723-733.

Charalambous, C. Y., Delaney, S., Hsu, H.-Y., \& Mesa, V. (2010). A Comparative analysis of the addition and subtraction of fractions in textbooks from three countries. Mathematical Thinking and Learning, 12(2), 117-151.

Charalambous, C. Y., \& Pitta-Pantazi, D. (2007) Drawing on a theoretical model to study students' understandings of fractions. Educational Studies in Mathematics, 64(3), 293-316. 
Cramer, K., \& Henry, A. (2002). Using manipulative models to build number sense for addition of fractions. In B. Litwiller (Ed), Making sense of fractions, ratios, and proportions (pp. 41-48). Reston, VA: NCTM.

Creswell, J. W., Plano Clark, V. L., Gutmann, M. L., \& Hanson, W. E. (2003). Advanced mixed methods research designs. In A. Tashakkori \& C. Teddlie (Eds.), Handbook of mixed methods in social and behavioral research (pp. 209-240). Thousand Oaks: SAGE.

Mullis, I. V. S., \& Martin, M. O. (Ed). (2013). TIMSS 2015 Assessment Framework. Chestnut Hill: TIMSS \& PIRLS International Study Center.

Ni, Y. J., \& Zhou, Y. D. (2005) Teaching and learning fraction and rational numbers: The origins and implications of whole number bias. Educational Psychologist, 40(1), $27-52$.

Hiebert, J., \& Grouws, D. A. (2007). The effects of classroom mathematics teaching on students' learning. In F. Lester (Ed), Second handbook of research on mathematics teaching and learning (pp. 371-404). Charlotte: Information Age Publishing.

Husén, T. (Ed). (1967). International study of achievement in mathematics: A comparison of twelve countries (Vol. II). New York: John Wiley \& Sons.

Kele, A., \& Sharma, S. (2014). Students' beliefs about learning mathematics: Some findings from the Solomon Islands. Teachers and Curriculum, 14(1), 33-44.

Kieren, T. E. (1976). On the mathematical, cognitive, and instructional foundations of rational numbers. In R. Lesh (Ed), Number and Measurement: Papers from a Research Workshop ERIC/SMEAC (pp. 101-144). Columbus: SMEAC.

Kiwanuka, H. N., Van Damme, J., Van Den Noortgate, W., Anumendem, D. N., Vanlaar, G., Reynolds, C., \& Namusisi, S. (2017). How do student and classroom characteristics affect attitude toward mathematics? A multivariate multilevel analysis. School Effectiveness and School Improvement, 28(1), 1-21.

Lamon, S. J. (1999). Teaching fractions and ratios for understanding. New Jersey: Lawrence Erlbaum Associates.

Schmidt, W. H., McKnight, C. C., Valverde, G. A., Houang, R. T., \& Wiley, D. E. (1997). Many visions, many aims: A cross-national investigation of curricular intentions in school mathematics. Dordrecht: Kluwer Academic Publishers.

Siebert, D., \& Gaskin, N. (2006). Creating, naming, and justifying fractions. Teaching Children Mathematics, 12(8), 394-400.

Tornroos, J. (2005). Mathematics textbooks, opportunity to learn and student achievement. Studies in Educational Evaluation, 31(4), 315-327.

Valverde, G. A., Bianchi, L. J., Wolfe, R. G., Schmid, W. H., \& Houang, R. T. (2002). According to the book. Using TIMSS to investigate the translation of policy into practice through the world of textbooks. Dordrecht: Kluwer Academic Publishers. 
Van de Walle, J. A., Karp, K. S., \& Bay-Williams, J. M. (2013). Elementary and Middle School Mathematics. Teaching developmentally. New Jersey: Pearson.

Wijaya, A., Van den Heuvel-Panhuizen, M., \& Doorman, M. (2015). Opportunity-tolearn context-based tasks provided by mathematics textbooks. Educational Studies in Mathematics, 89(1), 41-65.

Xin, Y. P. (2007). Word problem solving tasks in textbooks and their relation to student performance. Journal of Educational Research, 100(6), 347-359.

\section{Turkish Abstract}

Endonezyalı Dördüncü Sınıf Öğrencilerinin Kesirleri Öğenmedeki Güçlükleri ve Kesirleri Öğrenme Fırsatı Arasındaki İlişkiler: TIMSS Sonuçlarının Bir Kesiti

Bu makale, Endonezyalı dördüncü sınıf öğrencilerinin kesirleri öğrenmedeki zorlukları ve okuldaki öğrencilerin kesir bölümlerini öğrenme firsatı ile olan ilişkisini araştırmaktadır. Bu çalışmanın verileri, TIMSS 2015'ten alınmış olup, test sonuçları ve öğretmenlerin TIMSS Öğretmen Anketi'ne verdikleri yanıtlardan oluşmaktadır. Test ve anket verileri betimleyici istatistikler kullanılarak analiz edilmiştir. Bu çalışma, test ve ankete ek olarak, öğrenme firsatına daha kapsamlı bir içerik elde etmek için Endonezya'daki ders kitaplarının bir analizini de içermiştir. Ders kitaplarını analiz etmek için nitel yaklaşım kullanılmıștır. TIMSS sonuçlarının analizi, Endonezyalı öğrencilerin kesirleri kavramsal olarak anlamadıklarını göstermiştir.

Anahtar Kelimeler: program, 4. sınıf öğrencileri, kesirler, öğrenme firsatı, test kitabı, TIMSS

\section{French Abstract}

Les Relations entre les Difficultés d'Élèves de CM1 indonésiens dans Fractions et l'Occasion d'Apprendre Fractions : un Instantané de Résultats de TIMSS

Ce papier(journal) rapporte une exploration dans les difficultés des élèves de CM1 indonésiens dans des fractions et leur relation à l'occasion d'apprendre des étudiants de fractions obtenus aux écoles. Les données pour cette étude ont été dessinées(tirées) de 2015 TIMSS qui a compris des résultats de test et les réponses des professeurs au Questionnaire de Professeur TIMSS. Le test et les données de questionnaire ont été analysés en utilisant la statistique descriptive. Dans le complément(l'addition) pour tester et le questionnaire, cette étude a aussi inclus une analyse de manuels indonésiens pour obtenir une portée(un périmètre) plus large de l'occasion d'apprendre. L'approche qualitative a été utilisée pour analyser les manuels. L'analyse des résultats de TIMSS montre la compréhension conceptuelle basse des étudiants indonésiens de fractions.

Mots Clés: le programme d'études, des élèves de CM1, des fractions, l'occasion d'apprendre, des manuels, TIMSS

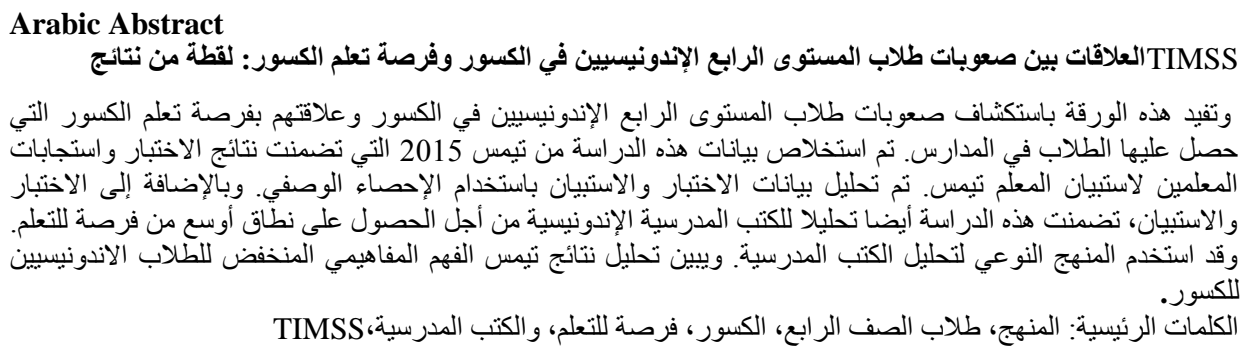




\title{
German Abstract \\ Die Beziehungen zwischen den Schwierigkeiten der indonesischen vierten Grader in Fraktionen und der Gelegenheit, Fraktionen zu erlernen: Ein Schnappschuss der TIMSS- Ergebnisse
}

Dieses Papier berichtet über eine Erforschung der Schwierigkeiten der indonesischen vierten Grader in Bruchteilen und ihre Beziehung zu der Gelegenheit, Fraktionen zu lernen, die Schüler an Schulen bekommen haben. Die Daten für diese Studie wurden aus TIMSS 2015 gezogen, die Testergebnisse und Lehrer Antworten auf TIMSS Lehrer Fragebogen enthalten. Die Test- und Fragebogendaten wurden anhand deskriptiver Statistiken analysiert. Zusätzlich zu Test und Fragebogen, diese Studie auch eine Analyse der indonesischen Lehrbücher, um einen breiteren Umfang der Gelegenheit zu lernen, um zu lernen. Qualitativen Ansatz wurde verwendet, um die Lehrbücher zu analysieren. Die Analyse der TIMSS-Ergebnisse zeigt das niedrige konzeptionelle Verständnis der indonesischen Studenten.

Schlüsselwörter: curriculum, vierte grader, fraktionen, gelegenheit zu lernen, lehrbücher, TIMSS

\begin{abstract}
Malaysian Abstract
Hubungan antara Kesukaran Gred Empat dalam Pecahan dan Peluang untuk Belajar Pecahan: Tangkapan Keputusan TIMSS

Makalah ini melaporkan penerokaan ke dalam kesulitan graduan bahasa Indonesia dalam pecahan dan hubungan mereka dengan peluang untuk belajar pecahan yang diperoleh di sekolah. Data untuk kajian ini telah diambil dari TIMSS 2015 yang terdiri daripada keputusan ujian dan respons guru terhadap Questionnaire Teacher TIMSS. Data ujian dan soal selidik dianalisis dengan menggunakan statistik deskriptif. Di samping ujian dan soal selidik, kajian ini juga termasuk analisis buku teks bahasa Indonesia untuk mendapatkan ruang lingkup yang lebih luas untuk belajar. Pendekatan kualitatif digunakan untuk menganalisis buku teks. Analisis keputusan TIMSS menunjukkan pemahaman konseptual yang rendah dari pelajar bahasa Indonesia tentang pecahan.
\end{abstract}

Kata Kunci: kurikulum, gred empat, pecahan, peluang untuk belajar, buku teks, TIMSS

\section{Russian Abstract \\ Отношения Между Трудностями Индонезийского Четвертого Грейдера во Фракциях и Возможность Изучения Фракций: Моментальный Снимок Результатов TIMSS}

В этой статье сообщается об исследовании трудностей четвертого класса индонезийцев в фракциях и их связи с возможностью изучения фракций, которые учащиеся получают в школах. Данные для этого исследования были взяты из TIMSS 2015, которые включали результаты теста и ответы учителей на Вопросник TIMSS. Данные теста и анкеты были проанализированы с использованием описательной статистики. В дополнение к тесту и анкете, это исследование также включало анализ индонезийских учебников, чтобы получить более широкий охват возможности обучения. Качественный подход был использован для анализа учебников. Анализ результатов TIMSS показывает низкое концептуальное понимание фракциями индонезийских студентов фракций.

Ключевые Слова: учебная программа, четвертый класс, фракции, возможность учиться, учебники, TIMSS 